\title{
Chenopodium album prevents progression of cell growth and enhances cell toxicity in human breast cancer cell lines
}

\author{
Menka Khoobchandani, ${ }^{1}$ B.K. Ojeswi, ${ }^{1}$ Bhavna Sharma ${ }^{2}$ and Man Mohan Srivastava ${ }^{1, *}$ \\ 'Department of Chemistry; Faculty of Science; Dayalbagh Educational Institute; Agra, India; ${ }^{2}$ National JALMA Institute for Leprosy and other Microbial disease; Agra, India
}

Key words: Chenopodium album, TBE bioassay, MTT bioassay, antiproliferative activity, anti breast cancer bioagent

The present study is aimed to investigate the effects of Chenopodium album (leaves) on the growth of estrogen dependent (MCF-7) and estrogen independent (MDA-MB-468) human breast cancer cell lines. The different solvent extracts (petroleum ether, ethyl acetate and methanol) were assessed for their cytotoxicity using TBE (Trypan blue exclusion) and MTT [3-(4, 5-dimethyl thiazol-2-yl)-2, 5-diphenyl tetrazolium] bioassay. These cells were cultured in MEM (minimum essential medium) medium and incubated with the dilution series of extracts $(10-100 \mathrm{mg} / \mathrm{ml})$ in $\mathrm{CO}_{2}$ incubator at $37^{\circ} \mathrm{C}$ for $24 \mathrm{~h}$. Among the various extracts studied for two cell lines, methanolic extract of $C$. album (leaves) exhibited maximum antibreast cancer activity having $\mathrm{IC}_{50}$ (the concentration of an individual compound leading to $50 \%$ inhibition) value $27.31 \mathrm{mg} / \mathrm{ml}$ against MCF-7 cell line. Significant percent inhibition (94.06\%) in the $\mathrm{MeOH}$ extract of $\mathrm{C}$. album (leaves) at $48 \mathrm{~h}$ of exposure and concentration $100 \mathrm{mg} / \mathrm{ml}(\mathrm{p}<0.05)$ against MCF-7 breast cancer cell line, indicates the presence of some structural moiety responsible for this observed antiproliferative effect. In vivo study and structural elucidation of its bioactive principle are in progress. Our findings highlight the potential of this plant for its possible clinical use to counteract malignancy development as antibreast cancer bioagent.

\section{Introduction}

Breast cancer is one of the most commonly occurring cancerous diseases. More than 10.5 lakhs new breast cancer cases occur worldwide annually while nearly 5.8 lakhs in developed countries remainder in developing countries. ${ }^{1}$ The lifetime risk of any particular woman getting breast cancer ranges from $2-5 \%$ in the world. ${ }^{2}$ In general, breast cancer rates have risen about 30\% in the past 25 years in western countries. ${ }^{3}$ Breast cancer now ranks first among

${ }^{*}$ Correspondence to: Man Mohan Srivastava; Department of Chemistry, Faculty of Science; Dayalbagh Educational Institute; Agra 282001 India; Tel.: +91.0562.2801545; Fax: +91.0562.2801226; Email: smohanm@rediffmail.com

Submitted: 03/23/09; Revised: 04/24/09; Accepted: 04/24/09

Previously published online as an Oxidative Medicine and Cellular Longevity E-publication:

http://www.landesbioscience.com/journals/oximed/article/8837 the causes affecting women throughout the world. It can also occur in men but rarely. As developing nations such as India, breast cancer is the leading cancer site in its female residents. ${ }^{4,5}$ The population based cancer registry data from various parts of the country, has revealed breast cancer as the commonest cancer among women in Delhi, Mumbai, Ahmedabad, Kolkata and Trivandrum. ${ }^{6}$

Several factors found to be responsible for initiation and promotion of breast cancer are genetic factors including genes like breast cancer antigens BRCA $1 \& 2$ having 85\% and 65\% risk of mammary carcinoma development respectively and nongenetic factors like use of hormone replacement therapies, high fat diet, intake of heterocyclic amines, late pregnancy, use of oral contraceptives, later age of menarche, earlier age of menopause etc. The present trend in the management of cancer development involves either reduction of the exposure of an individual to known carcinogens to the extent possible and or seeking advantage of the inhibitors of carcinogenesis for their eventual applications. Since exposure to the environmental carcinogens is often unavoidable, the latter field has been widely explored. Unfortunately, an alarming situation of drug resistance along with severe side effects is experienced and found environmentally harmful just because of the widespread and continued use of synthetics. A dose of chemotherapeutic drugs sufficient to kill tumor cells is often toxic to the normal tissue and lead to many side effects which in turn limit their treatment efficacy. Herbalism explains the unmistakable popularity of green magic bullets and is widely accepted in present perspectives. Plant-derived compounds comprise a diverse group with different mechanisms of actions, which seems to have the ability to induce apoptosis. ${ }^{7}$ Understanding the modes of action of plant-derived anti-cancer compounds provide useful information for their possible application in cancer prevention. ${ }^{8,9}$ It is thus important to screen apoptotic inducers from plants, either in the form of crude extracts or as components isolated from them. ${ }^{10}$ Medically screened plants which are used as traditional anticancer remedies increase the chance of finding new bioactive principles. Studies on the pharmacological mechanisms and searching for chemical structures from herbal extract for new anticancer drug caught great interest. ${ }^{11}$ Epidemiological studies have suggested that the medicinal plants can play a vital role in inhibiting the genotoxicity and carcinogenicity of anticancer drug 
to normal cells. ${ }^{12}$ Considering herbalism as an important strategy for cancer prevention, variety of animal experiments and cell lines culture have been carried out. ${ }^{13}$ Herbs of pharmacological importance are on the forefront whenever we talk about anticancer remedies. Vinblastine, Vincristine, Taxotere, Navelbine, Etoposide, Teniposide, Topotecan, Irinotecan, Doxorubicin, Dactomycin, Bleomycin and a number of other plant-derived anti-cancer compounds have been approved by United States Food and Drug Administration. ${ }^{14-16}$

Chenopodium album (bathua) is a wild neglected herb which has various pharmacological properties viz. antiviral, antifungal, anti-inflammatory, antiallergic, antiseptic and immunomodulating activity. ${ }^{17-20}$ However, not much attention seems to be paid for trapping anticancer activity of this plant. The phytochemicals like flavonoid, isoflavonoid, polyphenol etc., have garnered great interest for their potential role in the maintenance of human health in particular, significant cancer risk reduction. ${ }^{21}$ Presence of such allelochemicals in the above plant has prompted us to consider it for the present study.

In continuation of our work on herbal screening towards anticancer activity, ${ }^{22-24}$ the present communication reports in vitro effects of different solvent extracts of the plant C. album (leaves) on the growth of human breast cancer cell lines: breast adenocarcinoma estrogen receptor positive (MCF-7) and estrogen receptor negative (MDA-MB-468).

\section{Results}

Cytotoxic activity of different solvent extracts (Pt. ether, EtOAc and $\mathrm{MeOH}$ ) of $C$. album (leaves) was screened against human breast cancer cell lines MCF-7 and MDA-MB-468 with ten increasing concentrations $(10-100 \mathrm{mg} / \mathrm{ml})$ for $24 \mathrm{~h}$ first by the TBE and then followed by MTT bioassay. Pt. ether extract did not show any marked cytotoxic activity. Percent inhibition of EtOAc and $\mathrm{MeOH}$ extracts of the C. album (leaves) were calculated for MCF-7 and MDA-MB-468 cell lines and presented in subsequent Tables 1 and 2.

A perusal of Table $1 \mathrm{~A}$ and $\mathrm{B}$ indicates the presence of noticeable percent inhibition of EtOAc and $\mathrm{MeOH}$ extracts against MCF-7 cell line by the TBE and MTT bioassay. In case of EtOAc extract maximum inhibition $49.36 \%$ and for $\mathrm{MeOH}$ extract $87.43 \%$ was achieved at the concentration level of $100 \mathrm{mg} / \mathrm{ml}$ by the TBE assay while in MTT assay the growth of MCF-7 cells was inhibited upto $50.40 \%$ and $89.09 \%$ by EtOAc and $\mathrm{MeOH}$ extracts respectively at the concentration level of $100 \mathrm{mg} / \mathrm{ml}$.

Table $2 \mathrm{~A}$ and $\mathrm{B}$ present the data of percent inhibition of EtOAc and $\mathrm{MeOH}$ extracts generated from TBE and MTT bioassay against MDA-MB-468 cell line. EtOAc and $\mathrm{MeOH}$ extracts in TBE assay inhibit $27.54 \%$ and $48.65 \%$ respectively at the concentration level of $100 \mathrm{mg} / \mathrm{ml}$. In the MTT assay, growth was inhibited upto $28.63 \%$ and $49.77 \%$ by EtOAc and $\mathrm{MeOH}$ extracts respectively at the concentration level $100 \mathrm{mg} / \mathrm{ml}$.

\section{Discussion}

Well-defined route to natural product discovery has been opted as follows. Successive soxhalation was carried out in three organic solvents of increasing polarity (Pt. ether, EtOAc and $\mathrm{MeOH}$ ) to

\section{Table 1 (A) TBE (trypan blue exclusion) bioassay}

$\begin{array}{lccc}\text { S. No. } & \text { Conc } \mathbf{~ g} / \mathbf{m l} & \text { \% inhibition EtOAc } & \% \text { inhibition MeOH } \\ 1 & 10 & 7.04 \pm 1.31 & 15.34 \pm 1.34^{*} \\ 2 & 20 & 12.85 \pm 1.36 & 21.63 \pm 1.39 * \\ 3 & 30 & 16.45 \pm 1.41 & 26.74 \pm 1.42^{*} \\ 4 & 40 & 22.12 \pm 1.44 & 32.06 \pm 1.45^{*} \\ 5 & 50 & 27.42 \pm 1.49 & 41.56 \pm 1.51 * \\ 6 & 60 & 30.41 \pm 1.52 & 50.54 \pm 1.62^{*} \\ 7 & 70 & 36.21 \pm 1.61 & 60.12 \pm 1.68^{*} \\ 8 & 80 & 43.95 \pm 1.69 & 68.31 \pm 1.72 * \\ 9 & 90 & 46.42 \pm 1.71 & 75.38 \pm 1.73^{*} \\ 10 & 100 & 49.36 \pm 1.76 & 87.43 \pm 1.79 *\end{array}$

Increasing concentration of ethyl acetate and methanol extracts of Chenopodium album (leaves) leads to decreased cell proliferation and enhanced cell toxicity on MCF-7 (breast adenocarcinoma estrogen receptor positive) cell line. Cells were seeded in tissue culture petri plates and treated with plant extracts. $\mathrm{MeOH}$ extract exhibited significant antiproliferative activity and showing maximum $87.43 \%$ inhibition against cell line MCF-7 at the concentration $100 \mathrm{mg} / \mathrm{ml}$ at $24 \mathrm{~h}$. Results represent mean value of triplicate culture with SD. Students' unpaired t-test ${ }^{*} p<0.05$ vs. ethyl acetate extract.

\section{Table 1 (B) MTT [3-(4, 5-dimethyl thiazol-2-yl)-2, 5-diphenyl tetrazolium] bioassay}

$\begin{array}{lccc}\text { S. No. } & \text { Conc } \mathbf{~ m} / \mathbf{m l} & \text { \% inhibition EtOAc } & \text { \% inhibition MeOH } \\ 1 & 10 & 9.22 \pm 1.41 & 16.42 \pm 1.49^{*} \\ 2 & 20 & 13.41 \pm 1.46 & 22.72 \pm 1.50^{*} \\ 3 & 30 & 17.33 \pm 1.53 & 28.51 \pm 1.62^{*} \\ 4 & 40 & 23.20 \pm 1.59 & 34.06 \pm 1.65^{*} \\ 5 & 50 & 28.28 \pm 1.60 & 42.21 \pm 1.69^{*} \\ 6 & 60 & 32.20 \pm 1.64 & 52.81 \pm 1.73^{*} \\ 7 & 70 & 37.40 \pm 1.68 & 61.03 \pm 1.77^{*} \\ 8 & 80 & 44.23 \pm 1.72 & 70.42 \pm 1.86^{*} \\ 9 & 90 & 48.11 \pm 1.84 & 78.08 \pm 1.91 * \\ 10 & 100 & 50.40 \pm 1.92 & 89.09 \pm 1.97^{*}\end{array}$

Increasing concentration of ethyl acetate and methanol extracts of Chenopodium album (leaves) leads to decreased cell proliferation and enhanced cell toxicity on MCF-7 (breast adenocarcinoma estrogen receptor positive) cell line. Cells were seeded in tissue culture petri plates and treated with plant extracts. $\mathrm{MeOH}$ extract exhibited significant antiproliferative activity against cell line MCF-7 showing maximum $89.09 \%$ inhibition at the concentration $100 \mathrm{mg} / \mathrm{ml}$ at $24 \mathrm{~h}$. Results represent mean value of triplicate culture with SD. Students' unpaired t-test ${ }^{*} \mathrm{p}<0.05$ vs. ethyl acetate extract.

recover the wide range of organic compounds from the source. Recovery of organic compounds in three solvents followed by their bioassay leads to the characterization of most potent solvent extract. Chromatographic separation of most potent solvent extract followed by bioassay of each fraction provides the information of the most potent biologically active fraction. Finally structural elucidation of this most potent fraction ascertains the possible bioactive principle.

MCF-7 cells are well characterized estrogen receptor positive, non invasive differentiated mammary epithelium cells while MDA-MB-468 are highly invasive, estrogen independent and dedifferentiated breast carcinoma cell line. Above characteristics of these cell lines make them appropriate for in vitro model of 


\section{Table 2 (A) TBE (trypan blue exclusion) bioassay}

$\begin{array}{lccr}\text { S. No. } & \text { Conc } \mathbf{m g} / \mathbf{m l} & \text { \% inhibition EtOAc } & \text { \% inhibition MeOH } \\ 1 & 10 & 3.45 \pm 1.42 & 7.21 \pm 1.44^{*} \\ 2 & 20 & 5.98 \pm 1.45 & 10.54 \pm 1.45^{*} \\ 3 & 30 & 10.23 \pm 1.51 & 15.48 \pm 1.56^{*} \\ 4 & 40 & 12.23 \pm 1.55 & 20.54 \pm 1.61 \text { * } \\ 5 & 50 & 15.65 \pm 1.61 & 25.42 \pm 1.69 * \\ 6 & 60 & 19.32 \pm 1.68 & 30.12 \pm 1.70 * \\ 7 & 70 & 22.67 \pm 1.72 & 37.53 \pm 1.76 * \\ 8 & 80 & 25.43 \pm 1.76 & 41.98 \pm 1.82 * \\ 9 & 90 & 26.09 \pm 1.81 & 45.76 \pm 1.88^{*} \\ 10 & 100 & 27.54 \pm 1.84 & 48.65 \pm 1.92 *\end{array}$

Increasing concentration of ethyl acetate and methanol extracts of Chenopodium album (leaves) leads to decreased cell proliferation and enhanced cell toxicity on MDA-MB-468 (breast adenocarcinoma estrogen receptor negative) cell line. Cells were seeded in tissue culture Petri plates and treated with plant extracts. $\mathrm{MeOH}$ extract exhibited significant antiproliferative activity and showing maximum $48.65 \%$ inhibition against cell line MDA-MB-468 at the concentration $100 \mathrm{mg} / \mathrm{ml}$ at $24 \mathrm{~h}$. Results represent mean value of triplicate culture with SD. Students' unpaired t-test ${ }^{*} \mathrm{p}<0.05$ vs. ethyl acetate extract

Table 2 (B) MTT [3-(4, 5-dimethyl thiazol-2-yl)-2, 5-diphenyl tetrazolium] bioassay

$\begin{array}{lccr}\text { S. No. } & \text { Conc } \mathbf{m g} / \mathbf{m l} & \text { \% inhibition EtOAc } & \text { \% inhibition } \mathrm{MeOH} \\ 1 & 10 & 4.11 \pm 1.52 & 8.31 \pm 1.55^{*} \\ 2 & 20 & 7.20 \pm 1.56 & 12.24 \pm 1.59^{*} \\ 3 & 30 & 11.20 \pm 1.66 & 16.69 \pm 1.68^{*} \\ 4 & 40 & 13.32 \pm 1.72 & 21.22 \pm 1.72^{*} \\ 5 & 50 & 18.94 \pm 1.76 & 26.67 \pm 1.76^{*} \\ 6 & 60 & 21.01 \pm 1.83 & 31.32 \pm 1.79^{*} \\ 7 & 70 & 24.06 \pm 1.89 & 38.54 \pm 1.88^{*} \\ 8 & 80 & 26.12 \pm 1.91 & 43.01 \pm 1.89^{*} \\ 9 & 90 & 27.31 \pm 1.94 & 46.11 \pm 1.96^{*} \\ 10 & 100 & 28.03 \pm 1.97 & 49.77 \pm 2.01 \text { * }\end{array}$

Increasing concentration of ethyl acetate and methanol extracts of Chenopodium album (leaves) leads to decreased cell proliferation and enhanced cell toxicity on MDA-MB-468 (breast adenocarcinoma estrogen receptor negative) cell line. (ells were seeded in tissue culture Petri plates and treated with plant extracts. $\mathrm{MeOH}$ extract exhibited significant antiproliferative activity and showing maximum $49.77 \%$ inhibition against cell line MDA-MB- 468 at the concentration $100 \mathrm{mg} / \mathrm{ml}$ at $24 \mathrm{~h}$. Results represent mean value of triplicate culture with SD. Students' unpaired t-test ${ }^{*} p<0.05$ vs. ethyl acetate extract.

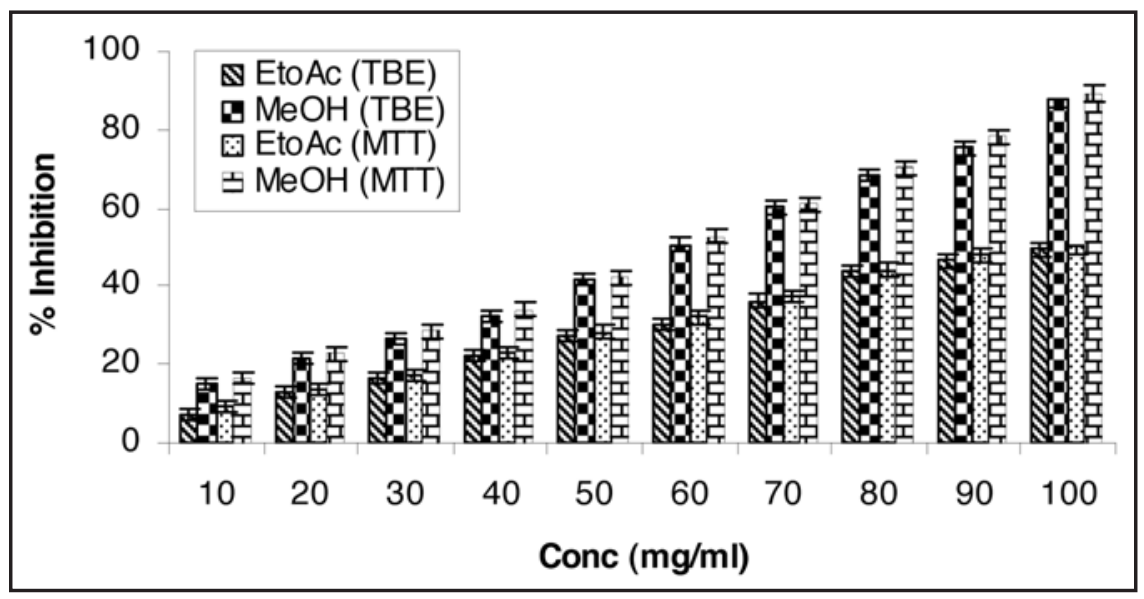

breast cancer ${ }^{25-29}$ and therefore have been considered for the present study. Further, current assays for measuring cytotoxicity are based on alterations of plasma membrane permeability and the consequent release of components into the supernatant or the uptake of dyes. In case of trypan blue exclusion assay, the dead cells uptake the dye while the viable cells are excluded. ${ }^{30}$ In MTT assay, dead cells are unable to metabolize yellow tetrazolium salt while viable cells metabolize yellow tetrazolium salt into purple formazan crystal. ${ }^{31}$ Thus the use of these two (TBE and MTT) bioassay provide real picture of percent inhibition of herbal extract and hence selected for the present study. ${ }^{32}$

Percent inhibition resulting from TBE and MTT bioassay demonstrated that both the extracts are the efficient candidates as cytotoxic bioagent (antibreast cancer activity) against the cell lines MCF-7 and MDA-MB-468. The percent inhibition for both the extracts showed more pronounced efficacy on MCF-7 particularly ( $\mathrm{p}<0.05$ ) compared to MDA-MB-468 cell line. It was also inferred that comparatively $\mathrm{MeOH}$ extract is more significant antibreast cancer agent against cell line MCF-7 showing maximum $89 \%$ inhibition at the concentration $100 \mathrm{mg} / \mathrm{ml}$ at $24 \mathrm{~h}(\mathrm{p}<0.05)$.

Attempts were also made to present our findings in graphical forms highlighting the significant cytotoxicity of $\mathrm{MeOH}$ extract against MCF-7 cell line (Figs. 1 and 2).

$\mathrm{IC}_{50}$ values (the concentration of an individual compound leading to $50 \%$ inhibition) calculated from MTT assay using probit analysis were as follows: C. album (leaves): MCF-7_EtOAc (37.62 mg/ml); $\mathrm{MeOH}(27.31 \mathrm{mg} / \mathrm{ml})$, MDA-MB-468—EtOAc (49.33 mg/ml); $\mathrm{MeOH}(36.02 \mathrm{mg} / \mathrm{ml})$. The regression constant and correlation coefficients were calculated for the EtOAc and $\mathrm{MeOH}$ extract of C. album (leaves) against MCF-7 cell line; Regression constant: EtOAc (0.48x + 3.89) and $\mathrm{MeOH}(0.81 \mathrm{x}+4.78)$; Correlation coefficient $(\mathrm{r})$ : EtOAc (0.98) and $\mathrm{MeOH}(0.99)$.

$\mathrm{MeOH}$ extract of the plant C. album (leaves) being potent, therefore, was further studied for its percent inhibition as a function of time $(24-96 \mathrm{~h})$ and dose $(20-100 \mathrm{mg} / \mathrm{ml})$. Maximum percent inhibition (94.06\%) in the $\mathrm{MeOH}$ extract of $C$. album (leaves) was achieved at $48 \mathrm{~h}$ of exposure at the concentration $100 \mathrm{mg} / \mathrm{ml}$ (Fig. 3).The trend showed that $48 \mathrm{~h}$ is the optimum time for significant antibreast cancer activity caused. On the basis of observed encouraging cytotoxic

Figure 1. TBE (Trypan blue exclusion) and MTT [3-(4, 5-dimethyl thiazol-2-yl)-2, 5-diphenyl tetrazolium] bioassay: Increasing concentration of ethyl acetate and methanol extracts of Chenopodium album (leaves) leads to decreased cell proliferation and enhanced cell toxicity on MCF-7 (breast adenocarcinoma estrogen receptor positive) cell line. Cells were seeded in tissue culture plates and treated with plant extracts. $\mathrm{MeOH}$ extract exhibited significant antiproliferative activity against cell line MCF-7 showing maximum $89.09 \%$ inhibition at the concentration $100 \mathrm{mg} / \mathrm{ml}$ at $24 \mathrm{~h}$ using MTT bioassay. Results represent mean value of triplicate cultures SD. Students' unpaired t-test $p<0.05$. 
effect by the in vitro bioassays, it can be revealed that $\mathrm{MeOH}$ extract of $C$. album (leaves) has promising antibreast cancer bioefficacy and must have some chemical moiety in the leaves part of this plant which might be responsible for observed beneficial effect. We suggest that the detailed in vivo studies should be carried out in animal experimental model of breast cancer. Screening of phytochemicals for anticancer activity is extremely important in today's context of a variety of tumors getting resistant to conventional anticancer drugs. Structural elucidation of bioactive principle of $\mathrm{MeOH}$ fraction of $C$. album (leaves) is to be worked out. The efforts on the above lines are in progress.

\section{Materials and Methods}

Cell culture. MCF-7 and MDA-MB-468 human breast cancer cell lines were procured from National Centre for Cell Sciences, Pune, India. Nutrient mixture F-12, culture medium MEM (Minimum Essential Medium), antibiotics and FBS (Fetal Bovine Serum) were purchased from Gibco BRL, USA. Culture wares and other plastic consumables used in the study were procured from Nunc, USA. Milli Q water was used throughout the experiment. Cells were grown in Nutrient mixture F-12, 82.5\% supplemented with $2.5 \%$ FBS, $0.2 \%$ sodium bicarbonate, antibiotic and antimycotic solution. The cells were grown in the following conditions: $5 \% \mathrm{CO}_{2}, 95 \%$ atmosphere in high humidity at $37^{\circ} \mathrm{C}$ in a $\mathrm{CO}_{2}$ incubator. Each batch of cells was assessed for cell cytotoxicity by TBE ${ }^{33}$ and MTT assay. ${ }^{34}$ Cells for passage number between 18-25 were used in the study.

Soxhalation. The shade dried powdered leaves of the plant C. album (leaves) were subjected to extraction successively with solvents of increasing polarity (Pt. ether, EtOAc and $\mathrm{MeOH}$ ). The residual portions, obtained after removing the respective solvent (vacuum distillation Rota vapor) were dried by purging nitrogen and finally weighed.

Experimental design. Cultured healthy cells were exposed to concentration range $(10-100 \mathrm{mg} / \mathrm{ml})$ of various extracts of C. album (leaves). The cells were subjected for the assessment of cytotoxic responses.

Trypan blue exclusion assay. Cells $\left(1 \times 10^{6} /\right.$ plate $)$ were seeded in poly-l-lysine precoated tissue culture petri plates and allowed to adhere for $24 \mathrm{~h}$ in $\mathrm{CO}_{2}$ incubator at $37^{\circ} \mathrm{C}$. The medium was replaced with incomplete MEM medium containing different concentrations of respective herbal extracts separately again for $24 \mathrm{~h}$ in $\mathrm{CO}_{2}$ incubator at $37^{\circ} \mathrm{C} .0 .1 \mathrm{ml}$ Trypan blue dye $(0.4 \%$ in water) was mixed with cell suspension, 15 min prior to completion of incubation period. At the end of incubation period, the petri plates were carefully taken out and $1.0 \%$ Sodium dodecyal sulfate was added to each petri plates by pipetting up and down several times unless the contents get homogenized and the number of viable cells (not stained) counted using a haemocytometer. Viability was expressed as a percentage of control number of cells

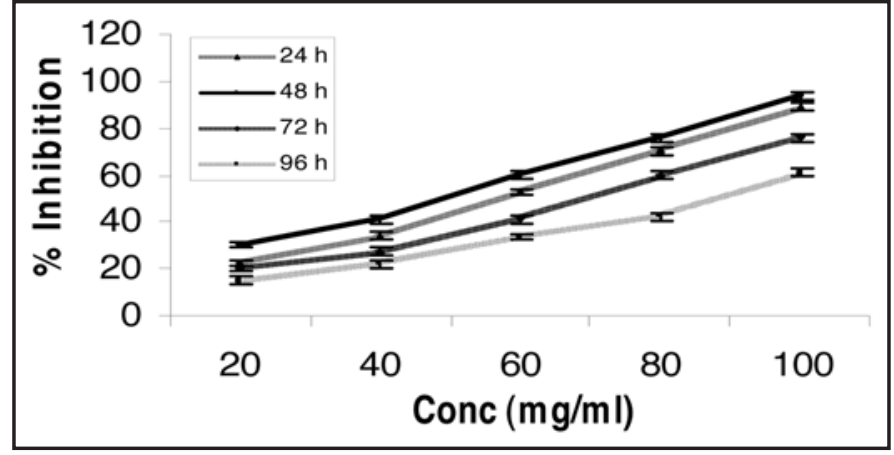

Figure 3. Percent inhibition, time and concentration dependency of methanol extract of Chenopodium album (leaves) on MCF-7 (breast adenocarcinoma estrogen receptor positive) cell line. $\mathrm{MeOH}$ extract exhibited significant percent inhibition (94.06\%) at $48 \mathrm{~h}$ of exposure at the concentration $100 \mathrm{mg} / \mathrm{ml}$ using MTT bioassay. Results represent mean value of triplicate cultures SD. Students' unpaired t-test $p<0.05$.

excluding Trypan blue dye. Although numbers of Trypan blue dye staining cells were not counted and it is recognized that these may be lost from the population relatively quickly.

Mitochondrial activity by MTT assay. Cells ( 1 x $10^{6} /$ well) were seeded in poly-l-lysine precoated 96 well tissue culture plates and allowed to adhere for $24 \mathrm{~h}$ in $\mathrm{CO}_{2}$ incubator at $37^{\circ} \mathrm{C}$. The medium was replaced with the serum free medium containing different concentrations of respective herbal extracts (10-100 mgml $\left.{ }^{-1}\right)$ separately again for $24 \mathrm{~h}$ in $\mathrm{CO}_{2}$ incubator at $37^{\circ} \mathrm{C}$. Tetrazolium bromide salt solution $(10 \mu \mathrm{l} /$ well $)$ was added in cell suspension $(100 \mu \mathrm{l})$, four hours prior to completion of incubation period. Periodically viewing the cells under an inverted microscope for the presence of intracellular punctuates purple precipitate, dimethyl sulfoxide $(200 \mu \mathrm{l})$ added to each well 


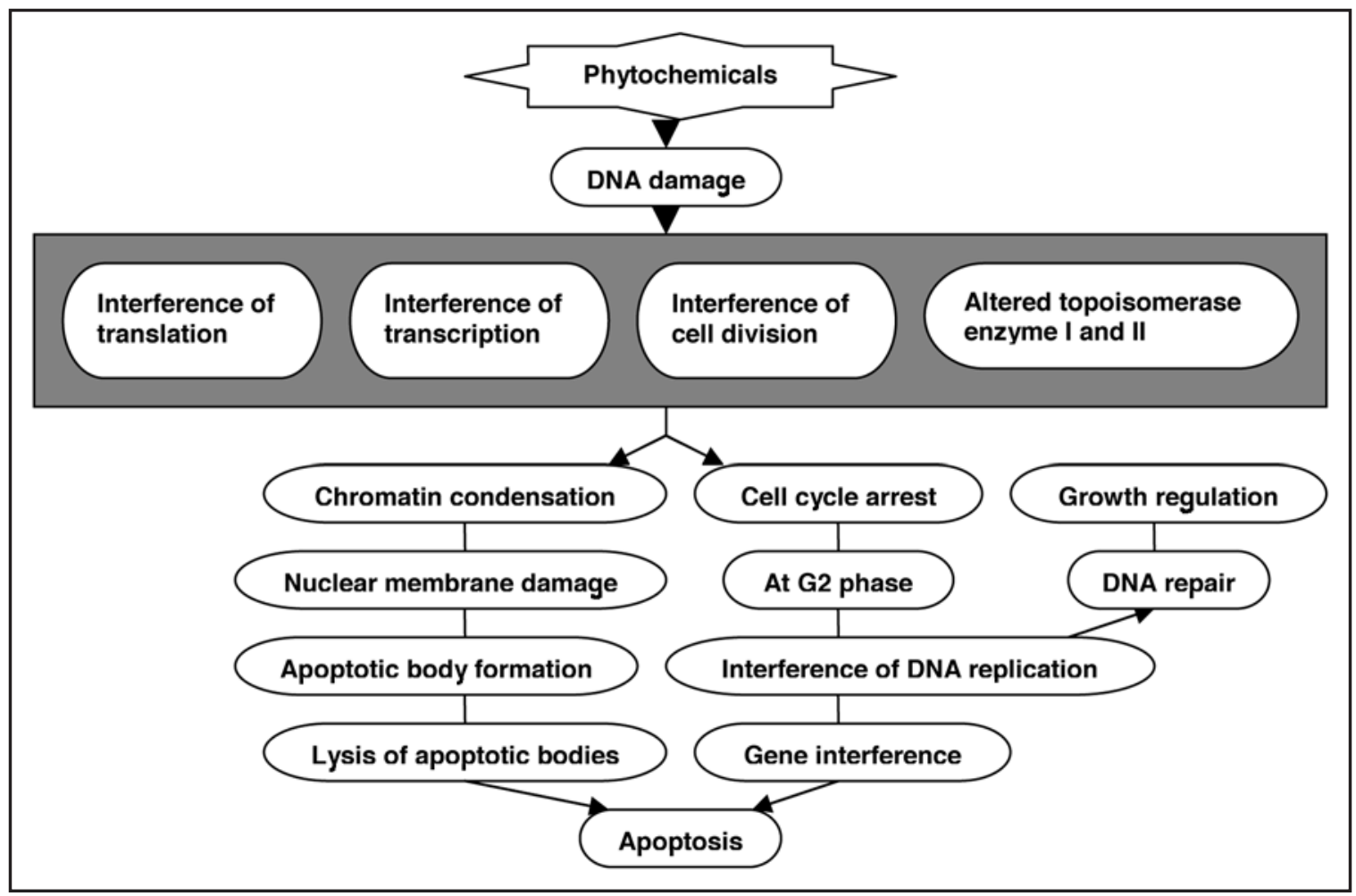

Figure 4. Potential of phytochemicals for apoptosis promotion and antiproliferative activity.

by pipetting up and down several times unless the contents get homogenized. Plate was placed in the dark for four hours at room temperature. The plates were kept on rocker shaker for $10 \mathrm{~min}$ at room temperature and then read at $550 \mathrm{~nm}$ using Multiwell microplate reader (Synergy HT, Biotech, USA). The average values were determined from triplicate readings and substract from the average values of the blank. Percent of inhibition was calculated by using the formula: Percent of inhibition $=(\mathrm{C}-\mathrm{T}) / \mathrm{C} \times 100$, where $\mathrm{C}=$ Absorbance of control, $\mathrm{T}=$ Absorbance of Treatment.

Statistical analysis. Data are expressed in percent inhibition with respect to the control. The percentages of cell inhibition were used to determine the $\mathrm{IC}_{50}$ values using probit analysis. ${ }^{35}$ Regression constant and correlation coefficient ( $\mathrm{r}$ ) have been calculated from log concentration versus probit inhibition.

\section{Acknowledgements}

The authors gratefully acknowledge Professor V.G. Dass, Director, Dayalbagh Educational Institute, Dayalbagh, Agra, for providing necessary research facilities. Dr. S.J.S. Flora, Joint Director, Division of Pharmacology and Toxicology, DRDE, Gwalior and Dr. B. Joshi, Department of Immunology, National JALMA Institute for Leprosy and other microbial disease, Agra are duly acknowledged for fruitful scientific discussions. M.K. and B.K.O. acknowledge University Grants Commission, New Delhi for providing Research Assistant Fellowships under Special Assistance Programme sanctioned to the Department.

\section{References}

1. Stewart WB, Kleihues P. WHO Worldwide Report of Breast Cancer 2001.

2. Parkin DM. Breast cancer: Statistics on incidence, survival and screening. ACS 2007; 7:1-4.

3. Hashemi M, Karami TF. Estrogen and Progesterone receptor status in tumor samples of Iranian breast cancer patients. Pak J Biol Sci 2006; 9:854-8.

4. Ghumare SS, Cunningham JE. Breast cancer trends in Indian residents and emigrants portend an emerging epidemic for India. Asian Pacific J Cancer Prev 2007; 8:507-12.

5. National Cancer registry Programme. Consolidated report of the population based cancer registries 2000-2006. Indian Council of Medical Research, New Delhi 2007.

6. Saxena S, Rekhi B, Bansal A, Bagga A, Chintamani, Murthy NS. Clinico-morphological patterns of breast cancer including family history in a New Delhi hospital, India-A crosssectional study. World J Surg Oncol 2005; 3:67-74.

7. Balachandran P, Govindarajan R. Cancer-an ayurvedic perspective. Pharmacol Res 2005; 51:19-30.

8. Dahab RA, Afifi F. Antiproliferative activity of selected medicinal plants of Jordan against a breast adenocarcinoma cell line (MCF-7). Sci Pharma 2007; 75:121-36.

9. Gallo D, Ferlini C, Fabrizi M, Prislei S, Scambia G. Lack of stimulatory activity of a Phytoestrogen containing soy extract on the growth of breast cancer tumors in mice. Carcinogenesis 2006; 27:1404-9.

10. Kirana C, Jones GP. Anticancer properties of panduratin A isolated from Boesenbergia pandurata (Zingiberaceae). J Nat Med 2007; 61:131-7.

11. Cragg GM, Newman DJ. Screening of natural and synthetic compounds for their antimicrobial and anticancer activity. Cancer Lett 1999; 17:153-62.

12. Samarth RM, Panwar M, Kumar A. Modulatory effects of Mentha piperita on lung tumor incidence, genotoxicity and oxidative stress in benzo(a)pyrene treated Swiss albino mice. Environ Mol Mutagen 2006; 47:192-8.

13. Muraoka CRS, Dumont N, Arteaga CL. Dual role of transforming growth factor $\beta$ in mammary tumorigenesis and metastasis progression. Clin Cancer Res 2005; 11:937-43.

14. Lee KH. Anticancer drug design based on plant-derived natural products. J Biomed Sci 1999; 6:236-50.

15. Nandi P, Talukdar G, Sharma A. Chemopreventive agents: Activity and their mechanism. Pharmacotherapy 1998; 41:53-5.

16. Greenwald P, Keloff G, Burch-Whitman C, Kramer BS. Chemoprevention. Cancer Chemother Pharmacol 1995; 45:31-49. 
17. Kumar R, Mishra AK, Dubey NK, Tripathi YB. Evaluation of Chenopodium album oil as a potential source of antifungal, antiaflatoxigenic and antioxidant activity. Int J Food Microbial 2007; 115:159-64.

18. Kaur C, Kapoor HC. Antioxidant activity and total phenolic content of some Asian vegetables. J Food Sci Technol 2002; 37:153-61.

19. Dai Y, Ye WC, Wang ZT, Matsuda H, Kubo M, But PPH. Antipruritic and antinociceptic effects of Chenopodium album L. in mice. J Ethnopharma 2002; 81:245-50.

20. Mousavi T, Asadi N, Tebyanian M. Study of Chenopodium album allergenic extract to induce allergic asthma in murine model. Iran J Immunol 2005; 23:166-71.

21. Prakash D, Nath P, Pal M. Composition of variation of nutrient content in leaves, seed protein, fat and fatty acids profile of Chenopodium species. J Food Sci Agric 1993; 62:203-8.

22. Ojeswi BK, Khoobchandani M, Hazra DK, Srivastava MM. Nutrition and dietary carcinogen: Risk and aggressiveness. Natl Acad Sci Lett 2008; 31:311-8.

23. Ojeswi BK, Khoobchandani M, Hazra DK, Srivastava MM. Green chemicals: Prospect and future in designing new drugs for cancer. Int J Waste Water Treatment and Green Chem 2009; In press.

24. Ojeswi BK, Khoobchandani M, Arora JK, Hazra DK, Srivastava MM. In vitro antibreast cancer efficacy of two indigenous plants on human cancer cell line MCF-7. Natl Acad Sci Lett 2009; In press.

25. Kasper G, Reule M, Tschirchmann M, Dankert N. Stromelysin-3-overexpression in MCF-7 and MDA-MB-231 breast cancer cell lines: Involvement of the IGF-1 signaling pathway. BMC Cancer 2007; 7:1-12.

26. Okeke CU, Elekwa I. Proximate and preliminary analyses of Avocado Pearpersa gratissima Gaertn F. Nigerian J of Botany 2006; 19:156-62.

27. Kaur K, Wododo N, Nagpal A, Kaul SC, Wadhwa R. Sensitization of human cancer cells to anticancer drugs by leaf extract of Ashwagandha (Lash). Tiss Cult Res Commun 2007; 26:193-9.

28. Sun CL, Yuan JM, Koh WP, Yu MC. Green tea, black tea and breast cancer risk: A meta analysis of epidemiological studies. Carcinogenesis 2006; 27:1310-5.

29. Chamras H, Barsky SH, Ardashian A, Navasartian D, Heber D, Glaspy AJ. Novel interaction of vitamin $\mathrm{E}$ and estrogen in breast cancer. Nutr Cancer 2005; 52:43-8.

30. Baliga R, Zhang Z, Shah SV. Role of cytochrome P-450 in hydrogen peroxide-induced cytotoxicity to LLC-PK1 cells. Kid Intl 1996; 50:11-8.

31. Kumar VP, Shashidharaa S, Kumar MM, Sridharab BY. Cytoprotective role of Solanum nigrum against gentamicin-induced kidney cell Vero cells/damage in vitro. Fitoterapia $2001 ; 72: 481-6$

32. Mbarek LA, Mouse HA, Elabbadi N, Bensalah M, Gamouh A, Aboufatima R. Antitumor properties of blackseed (Nigella sativa L.) extracts. Braz J Med Biol Res 2007 40:839-47.

33. Frieauff W, Hartman A, Suter W. Automatic analysis of slides processed in the Comet assay. Mutagenesis 2001; 16:133-7.

34. Pandey MK, Pant AB, Dass M. In vitro cytotoxicity of polycyclic aromatic hydrocarbon residues arising through repeated fish dried oil in human hepatoma $\mathrm{HepG}_{2}$ cell line. Toxicol 2006; 20:308-16.

35. Finney DJ. Probit analysis. III Edn. Trumpington Street, Cambridge: Cambridge University 1971; 1-323. 


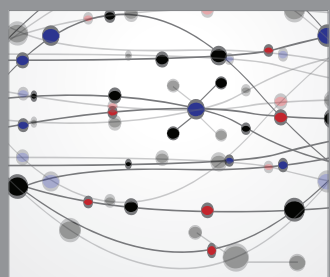

The Scientific World Journal
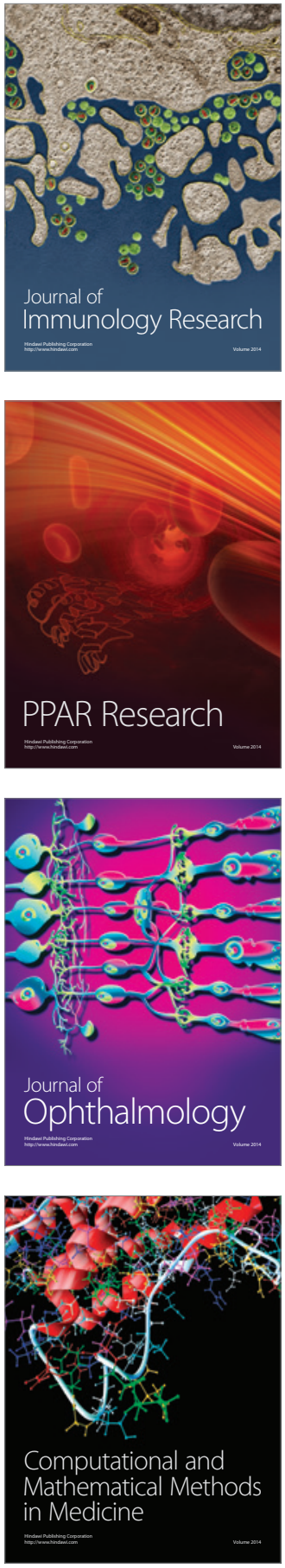

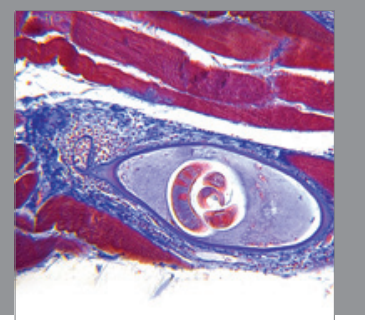

Gastroenterology

Research and Practice
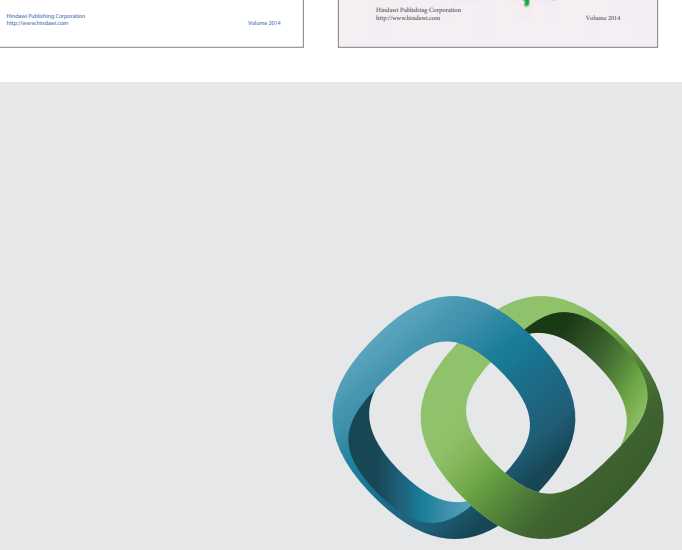

\section{Hindawi}

Submit your manuscripts at

http://www.hindawi.com
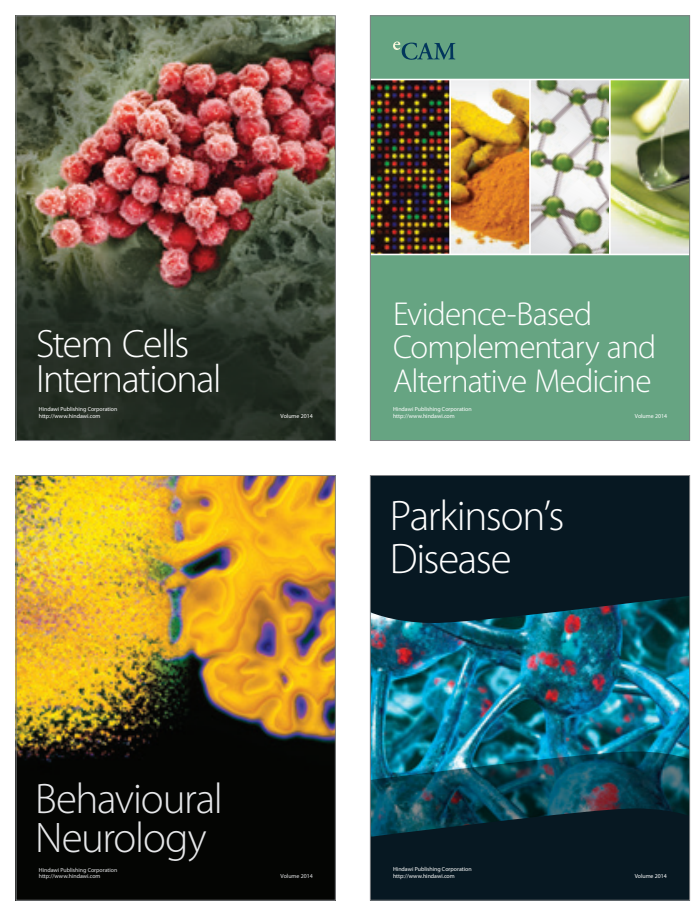

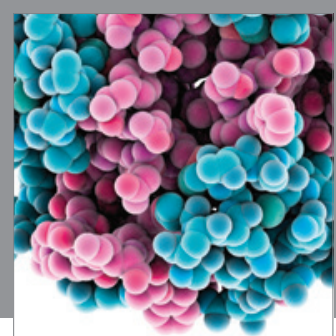

Journal of
Diabetes Research

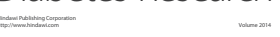

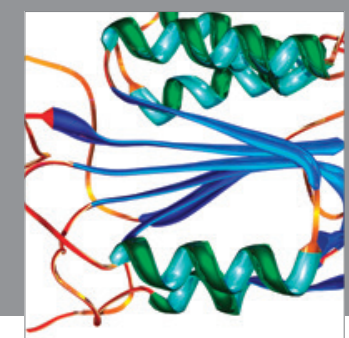

Disease Markers
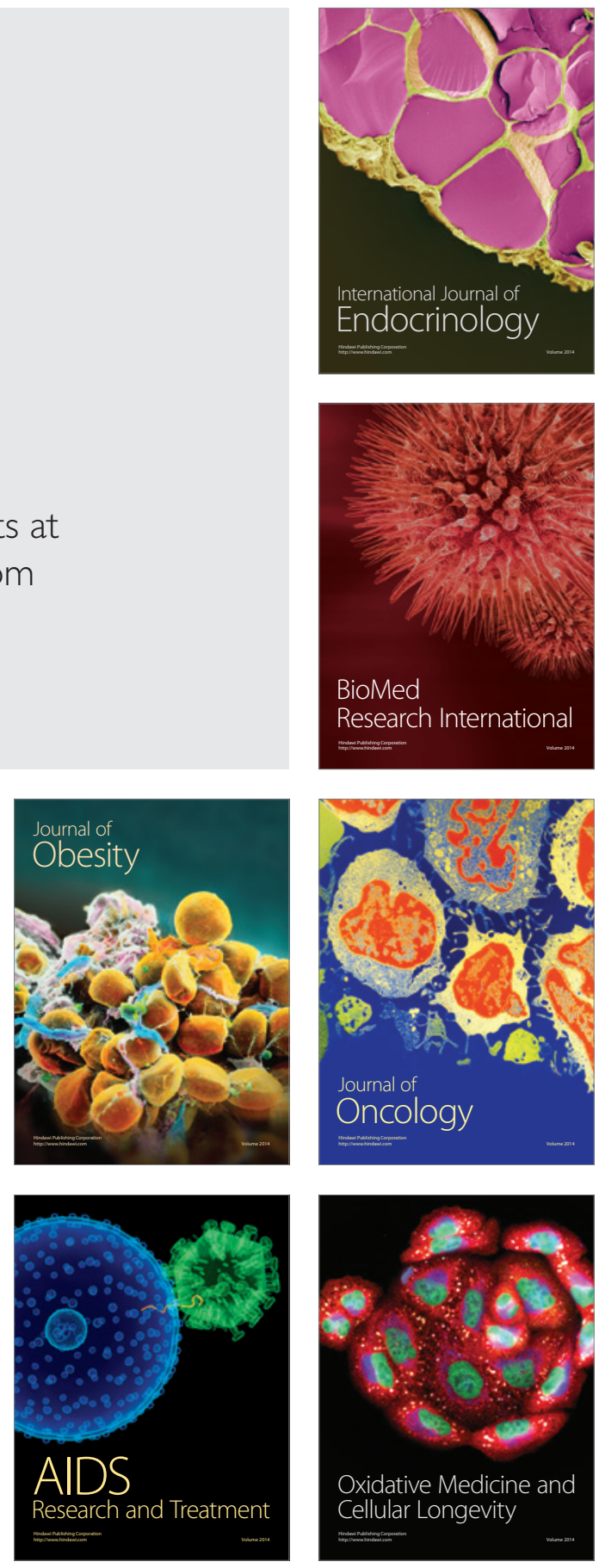